\title{
Innovative Notation System for Effective Reading and Thinking Strategy in Covid 19 Learning and Teaching Pandemonium
}

\author{
Djunaidi $^{1 *}$, Hermansyah ${ }^{2}$, Aswadi Jaya ${ }^{2}$
}

\author{
${ }^{1}$ Sriwijaya University, Indonesia \\ ${ }^{2}$ University PGRI Palembang, Indonesia \\ *Corresponding author.E-mail: djunaidi@unsri.ac.id
}

\begin{abstract}
Encouraging reading to the students who have the opportunity to do so, and shaping on providing educational support to those who do not, we can take small, yet impactful, steps towards combatting illiteracy during this Covid 19 pandemonium through Innovative Notation System For Effective Reading And Thinking . Therefore, the main objective of this study was to find out whether or not there was significant difference of students' reading in narrative texts taught by using Innovative Notation System For Effective Reading and Thinking Strategy and taught without using the strategy. The method of the research that was used in this study was a quasi-experimental design. The population of this study was all of the eighth grade students of State Junior High School 1 Palembang in the academic year of 2019/2020 with the total 251 students. The sample was 60 students divided into two groups they were experimental and control group. The sample was taken by using purposive sampling. The data were collected by written test. The test was given from multiple-choice that consisted of 40 test items and analyzed by using independent sample t-test formula. The result shows that the level with df 29 (30-1) was 1.671 and t-obtained 6.27. It means that t-obtained was higher than t-table 1.671 as critical value. Consequently, the alternative hypothesis (Ha) was accepted and null hypothesis (Ho) was rejected.
\end{abstract}

Keywords: Reading and Thinking Strategy, Learning in Covid-19, Notation System

\section{INTRODUCTION}

The brain is a muscle that requires strengthening to further its development. [1]Reading is a simple activity to help keep students' minds stimulated and focused during the global upheaval that has created many barriers to education.[2] Reading is cognitive process in which brain does most of works when reading, and this incredible human's device almost simultaneously takes information provided by eyes and then connects it with already known information related to subject in order to construct complete meaning of a text. [3] Not only does reading feed students' intellect and curiosity towards literacy, [4] but it also aids the development of crucial skills such as [5] analytical thinking, creativity, and comprehension. In Junior high school English teaching, [6] reading is one of the significant skills that needs to be acquired by students aside from writing, speaking, and listening in intention for students to be able to use English in communication skill and written skill. According to Joshon [7] and Sejnot [8] reading is the practice of using text to create meaning. If there is no meaning being created, [9] there is no reading taking place. Moreover, the purpose of reading process is acquiring information, knowledge, insight, and also understandment that is gotten from reading materials.[10] According to Umar, et al., (2020) Understanding," "knowledge," and "comprehension" are words we often use to describe what we want to achieve through the act of reading [21]. By understanding, it means we get the point of the text that we have read. [11] and [12] If we have understood what the text about, we gain knowledge and information. After that, we can comprehend the text. Reading is very important for us because by reading, we can gain some assistances, such as improving or increasing our knowledge as well as enhance the level of vocabulary we have.Without reading we will have a hardship to understand something and our literacy will be left behind.

Furthermore, [13] points out the purpose of extensive reading will be to train the student to read directly and fluently in the target language for enjoyment, [14] without the aid of the teacher. The 
purpose for reading guide the student's selection of text based on their appropriate age. There are some kinds of text of English, They are descriptive, recount, report, narrative and procedure. [15] Based on syllabus in second semester, English lesson for the eighth grade focused on narrative and recount text. In this research, the writer choosed narrative text to be taught for eighth grade because narrative text can entertain the students and the story of narrative text was imaginative for them. [23] According to Sari \& Suhono Narrative texts include realistic fiction, fantasy, fairytales, folktales, fables, mysteries, humor, historical fiction, plays, and real-life adventures.[16][17] That's why when the students read the story in narrative text,they have to know about what narrative is, what important event happen in narrative text, and knowing about the purpose of narrative text.[18]

In order to develope students' reading skill, teachers should look for any suitable way to manage the teaching-learning process in the classroom. [14]suitable strategy is needed to keep the students motivated to read the whole part of the text and increase their reading skill. Therefore, the researcher would like to apply a strategy that might help the students improve their ability in reading narrative text namely Innovative Notation System for Effective Reading and Thinking (INSERT) strategy.

\section{METHODS}

The method that was used to conduct this study was experimental method. Experimental research [19] and [20] which comes out of the framework of scientific realism, is thought by many to be the only type of research that results in findings that [22] suggest causal relationship. In this research, the writer used quasi experimental design with two classes. There were eight meetings include one meeting of pretest, six meetings of treatment, and one meeting of posttest. The population of this study was all the students of the eighth grade students of State Junior High School 1 Palembang in the academic year 2019-2020. There were 11 classes and they consisted of 251 students. The sample in this research were VIII. 7 as experimental group and VIII. 8 as control group. From the title of this study, the dependent variable was the result of students' reading achievement and independent variable was Innovative Notation System for Effective Reading and Thinking (INSERT) strategy. In collecting the data for this study, the writer used written test.

\section{RESULTS AND DISCUSSION}

The Students' Scores In Post-Test of Experimental Group

\begin{tabular}{|c|c|c|c|c|c|}
\hline $\begin{array}{c}\text { Students } \\
\text { Number }\end{array}$ & $\begin{array}{c}\text { Number of } \\
\text { Items }\end{array}$ & $\begin{array}{c}\text { Correct } \\
\text { Answer }\end{array}$ & $\mathbf{X}_{\mathbf{1}}$ & $\mathbf{x}_{\mathbf{1}}-\bar{X}_{\mathbf{1}}$ & $\left(\mathbf{x}_{\mathbf{1}}-\bar{X}_{1}\right)^{\mathbf{2}}$ \\
\hline 1 & 40 & 28 & 70 & -10.91666667 & 119.1736111 \\
\hline 2 & 40 & 34 & 85 & 4.0833333333 & 16.67361111 \\
\hline 3 & 40 & 36 & 90 & 9.0833333333 & 82.50694444 \\
\hline 4 & 40 & 26 & 65 & -15.91666667 & 253.3402778 \\
\hline 5 & 40 & 28 & 70 & -10.91666667 & 119.1736111 \\
\hline 6 & 40 & 26 & 65 & -15.91666667 & 253.3402778 \\
\hline 7 & 40 & 30 & 75 & -5.916666667 & 35.00694444 \\
\hline 8 & 40 & 36 & 90 & 9.0833333333 & 82.50694444 \\
\hline 9 & 40 & 33 & 82.5 & 1.5833333333 & 2.506944444 \\
\hline 10 & 40 & 29 & 72.5 & -8.416666667 & 70.84027778 \\
\hline 11 & 40 & 33 & 82.5 & 1.583333333 & 2.506944444 \\
\hline 12 & 40 & 38 & 95 & 14.08333333 & 198.3402778 \\
\hline 13 & 40 & 33 & 82.5 & 1.583333333 & 2.506944444 \\
\hline
\end{tabular}




\begin{tabular}{|c|c|c|c|c|c|}
\hline 14 & 40 & 28 & 70 & -10.91666667 & 119.1736111 \\
\hline 15 & 40 & 29 & 72.5 & -8.416666667 & 70.84027778 \\
\hline 16 & 40 & 30 & 75 & -5.916666667 & 35.00694444 \\
\hline 17 & 40 & 33 & 82.5 & 1.583333333 & 2.506944444 \\
\hline 18 & 40 & 37 & 92.5 & 11.58333333 & 134.1736111 \\
\hline 19 & 40 & 34 & 85 & 4.083333333 & 16.67361111 \\
\hline 20 & 40 & 32 & 80 & -0.916666667 & 0.840277778 \\
\hline 21 & 40 & 38 & 95 & 14.08333333 & 198.3402778 \\
\hline 22 & 40 & 38 & 95 & 14.08333333 & 198.3402778 \\
\hline 23 & 40 & 37 & 92.5 & 11.58333333 & 134.1736111 \\
\hline 24 & 40 & 35 & 87.5 & 6.583333333 & 43.34027778 \\
\hline 25 & 40 & 30 & 75 & -5.916666667 & 35.00694444 \\
\hline 26 & 40 & 28 & 70 & -10.91666667 & 119.1736111 \\
\hline 27 & 40 & 24 & 60 & -20.91666667 & 437.5069444 \\
\hline 28 & 40 & 37 & 92.5 & 11.58333333 & 134.1736111 \\
\hline 29 & 40 & 36 & 90 & 9.083333333 & 82.50694444 \\
\hline 30 & 40 & 35 & 87.5 & 6.583333333 & 43.34027778 \\
\hline$\sum \mathrm{x}_{1}$ & & & 2427.5 & & 3043.541667 \\
\hline $\bar{X}$ & & & 80.91 & & \\
\hline
\end{tabular}

Based on the table, the total score of students was 2427.5. To get mean score of post-test in experimental group, the total score of students was divided by total number of students 30 and the average score was 80.91 .

Total score $\sum \mathrm{x}_{1}=2427.5$

Mean $(\bar{X})=\frac{\sum \mathrm{x} 1}{n}=\frac{2427.5}{30}=80.91$
Variance $\left(s^{2}\right)=\frac{\sum\left(X_{1}-\overline{X_{1}}\right)^{2}}{n-1}=\frac{3043541667}{30-1}=$ $\frac{3043541667}{29}=104.9497$

Standard Deviation $(s)=\sqrt{\frac{\sum\left(X_{1}-\overline{X_{1}}\right)^{2}}{n-1}}$ $=\sqrt{\frac{3043.541667}{29}}=\sqrt{104.9497}$

$=10.244$.

The Students' Scores in Post-Test of Control Group

\begin{tabular}{|c|c|c|c|c|c|}
\hline $\begin{array}{c}\text { Students } \\
\text { Number }\end{array}$ & $\begin{array}{c}\text { Number of } \\
\text { Items }\end{array}$ & $\begin{array}{c}\text { Correct } \\
\text { Answer }\end{array}$ & $\mathbf{x}_{\mathbf{1}}$ & $\mathbf{x}_{\mathbf{1}}-\bar{X}_{1}$ & $\left(\mathbf{x}_{\mathbf{1}}-\bar{X}_{1}\right)^{\mathbf{2}}$ \\
\hline 1 & 40 & 19 & 47.5 & -15.83333333 & 250.6944444 \\
\hline 2 & 40 & 22 & 55 & -8.333333333 & 69.44444444 \\
\hline 3 & 40 & 25 & 62.5 & -0.833333333 & 0.694444444 \\
\hline 4 & 40 & 16 & 40 & -23.33333333 & 544.4444444 \\
\hline 5 & 40 & 19 & 47.5 & -15.83333333 & 250.6944444 \\
\hline 6 & 40 & 17 & 42.5 & -20.83333333 & 434.0277778 \\
\hline 7 & 40 & 23 & 57.5 & -5.833333333 & 34.02777778 \\
\hline 8 & 40 & 22 & 55 & -8.333333333 & 69.44444444 \\
\hline 9 & 40 & 26 & 65 & 1.666666667 & 2.777777778 \\
\hline 10 & 40 & 25 & 62.5 & -0.833333333 & 0.694444444 \\
\hline 11 & 40 & 27 & 67.5 & 4.166666667 & 17.36111111 \\
\hline
\end{tabular}




\begin{tabular}{|c|c|c|c|c|c|}
\hline 12 & 40 & 27 & 67.5 & 4.166666667 & 17.36111111 \\
\hline 13 & 40 & 33 & 82.5 & 19.16666667 & 367.3611111 \\
\hline 14 & 40 & 30 & 75 & 11.66666667 & 136.1111111 \\
\hline 15 & 40 & 26 & 65 & 1.666666667 & 2.777777778 \\
\hline 16 & 40 & 19 & 47.5 & -15.83333333 & 250.6944444 \\
\hline 17 & 40 & 30 & 75 & 11.66666667 & 136.1111111 \\
\hline 18 & 40 & 27 & 67.5 & 4.166666667 & 17.36111111 \\
\hline 19 & 40 & 32 & 80 & 16.66666667 & 277.7777778 \\
\hline 20 & 40 & 27 & 67.5 & 4.166666667 & 17.36111111 \\
\hline 21 & 40 & 28 & 70 & 6.666666667 & 44.44444444 \\
\hline 22 & 40 & 26 & 65 & 1.666666667 & 2.777777778 \\
\hline 23 & 40 & 35 & 87.5 & 24.16666667 & 584.0277778 \\
\hline 24 & 40 & 29 & 72.5 & 9.166666667 & 84.02777778 \\
\hline 25 & 40 & 23 & 57.5 & -5.833333333 & 34.02777778 \\
\hline 26 & 40 & 22 & 55 & -8.333333333 & 69.44444444 \\
\hline 27 & 40 & 26 & 65 & 1.666666667 & 2.777777778 \\
\hline 28 & 40 & 27 & 67.5 & 4.166666667 & 17.36111111 \\
\hline 29 & 40 & 24 & 60 & -3.333333333 & 11.11111111 \\
\hline 30 & 40 & 28 & 70 & 6.666666667 & 44.44444444 \\
\hline$\sum \mathrm{x}_{1}$ & & & 1900 & & 3791.666667 \\
\hline $\bar{X}$ & & & 63.33 & & \\
\hline
\end{tabular}

Based on the table, the total score of students was 1900. To get mean score of post-test in control group, the total score of students was divided by total number of students 30 and the average score was 63.33 .

Total score $\sum \mathrm{x}_{1}=1900$

Mean $(\bar{X})=\frac{\sum x 1}{n}=\frac{1900}{30}=63.33$

The students's average scores of post-test in experimental group were 80.91. The highest scores was 95 reached by three students and the lowest score was 60 reached by one student. The students' average scores of post-test in control group were 63.33. The highest score was 87.5 reached by one student and the lowest score was 40 reached by one student. It means there was significance different between the students' posttest in experiment group scores and the post-test in control group scores. The students' scores in posttest of experimental group were significantly higher than the students' scores in post-test control group.

Furthermore, the t-obtained showed that the alternative hyphothesis with significance level
Variance $\left(s^{2}\right)=\frac{\sum\left(X_{1}-\overline{X_{1}}\right)^{2}}{n-1}=\frac{3791666667}{30-1}=$ $\underline{3791,666667}=130.74$ 29

Standard Deviation $(\mathrm{s})=\sqrt{\frac{\sum\left(X_{1}-\overline{X_{1}}\right)^{2}}{n-1}}$ $=\sqrt{\frac{3791.666667}{29}}=\sqrt{130.747126}=11.4$

with df 29 (30-1) was accepted, because the result of the calculation of the independent t-test formula was 6.27, Meanwhile the value of t-table was 1.671 at significance level of 0.05 and with one tailed testing. Since the t-obtained 6.27 was higher than $\mathrm{t}$ table consequently the null hypothesis (Ho) was rejected and alternative hypothesis (Ha) was accepted.

\section{CONCLUSION}

Based on the result of the calculation of the scores in experimental group and control group. It was found that the t-obtained was 6.27 at the significant level 0.05 for one tailed test. Since the value of the t-obtained was higher than the value of t-table $(6.27>1.671)$ consequently the null 
hypothesis (Ho) was rejected and the alternative hypothesis (Ha) was accepted. It means that there was significant difference between teaching reading through Innovative Notation System for Effective Reading and Thinking (INSERT) strategy and those who were taught by conventional method in eighth grade students in State Junior High School 1 Palembang.

\section{REFERENCES}

[1] Alyousef, H. S. (2005). Teaching Reading Comprehension To Esl/Efl Learners. The Reading Matrix, 5(2), 143-154. (Vol. 5, No. 2, September 2005)

[2] Andela, M,\& Dahler. (2017) The Effect Of IRE (Initiation Response-Evaluation) Strategy in Teaching Reading Comprehension of Narrative Text at The First Grade Of SMAN Olahraga Riau Pekanbaru. Jurnal Pendidikan, ELT-Lectura (Vol 4, No 2, Agustus 2017)

[3] Suhono, S. (2019). Providing explicit strategy instruction to enhance students'reading comprehension at english for islamic studies class. JURNAL SMART, 5(2), 81-93.

[4] Brown, H. D. (2007). Principles of Language Learning and Teaching, Fifth Edition. USA: Pearson Education, Inc.

[5] Cohen, L. Manion, L., \& Morrison, K. (2005). Research Method in Education, Sixth Edition. New York: Routledge.

[6] Scharer, P. L. (2012). What is reading?. America: Ohio State University.

[7] Johnson, A. P. (2008). Teaching Reading and Writing: A Guide Book for Tutoring and Remediating Students. New York: Rowman and Littlefield Education

[8] Sejnost, R. L., \& Thiese, S. M. (2010). Building Content Literacy Strategies For Adolescent Learner. India, New Delhi: Corwin Sage Company.

[9] Harmer, J. (2001). How to Teach English, Seventh Impression. Malaysia: Longman.

[10] Anwar, A. K. (2020). The Effect of Collaborative Strategic Reading Toward Students Reading Skill. Anglophile Journal, 1(1), 21-28.

[11] Klingner, Janetter, K., et al. (2007). Teaching Reading Comprehension to the
Students with Learning Difficulties. New York: The Guilford Press

[12] Gregory, R. J. (2015). Psychological Testing; History, Principles, and Applications. Seventh Edition. United States: Pearson Education Limited.

[13] Patel M F., \& Jain, P. M. (2008). English Language Teaching, (Methods, Tools, Techniques). Jaipur: Sunrise Publisher \& Distributor.

[14] Lems, K., Leah, D., et al. (2010). Teaching Reading to English Language Learners. New York : The Guildford Press.

[15] Jaya, A. Hermansyah, Mortini, A. 2018. The Effect of Crawford Series Teaching (CST) on the Students' Writing Achievement. ESTEEM: Journal of English Study Program. 1(1).

[16] Sari, Y. A., \& Suhono, S. (2017). Applaying Transition Action Detail Strategy on Written Text of EFL Young Learners. Jurnal Iqra': Kajian Ilmu Pendidikan, 2(1), 1-24.

[17] Sari, Y. A. (2018). Applaying tell and show strategy on writtent text of young learners. Pedagogy: Journal of English Language Teaching, 6(1), 23-36.

[18] Suhono, S., \& Sari, D. A. (2020). Developing Students' Worksheet Based Educational Comic for Eleventh Grade of Vocational High School Agriculture. Anglophile Journal, 1(1), 29-40.

[19] Wahyudi, P. (2016). The Effect Of Save Interactive Notation System For Effective Reading And Thinking Strategy Toward Students' Reading Achievement A Study At Grade Xi Of Sma N 12 Padang. In Jurnal Pendidikan dan Pengajaran.

[20] Jaya, A. (2017). The influence of the Teachers' Questioning Strategies on the Eleventh Grade Students' Speaking Achievemnet at SMKN 1 Palembang. Jambi-English Language Teaching. 2 (1).

[21] Umar Al Faruq, A. H., Sari, Y. A., \& Puspita, N. (2020). Applying of Cooperative Integrated Reading and Composition (CIRC) Strategy on Students' Reading Comprehension. Anglophile Journal, 1(1), 41-47. 
[22] Fraenkel, J.R., Wallen, N. E., \& Hyun, H. H. (2012). How to design and evaluate research in education (8th ed). New York: McGraw-hill.

[23] Wiratna, M. Z. M. E., \& Hamdiah, H. (2020). A Correlation Between Students' Intelligence Quotient (IQ) and Their Writing Ability for the Eighth Grade. Anglophile Journal, 1(1), 12-20. 